\title{
The Analysis of the Character of Tess of the D'Urbervilles
}

\author{
Peng Yuan-yuan \\ Tourism Department of Leshan Vocational \& Technical College, China
}

\begin{abstract}
Tess is the outstanding realistic writer Thomas Hardy's typical criticism of the old moral characters. Tess marks the birth of the new image of new agricultural workers, even though she is weak in the thoughts, but in front of the disaster of fortitude and dedication, sacrifice made her become a tragic character. In Hardy's eyes, Tess's all gifts were her greatest beauty, and she was a pure man. But she was tortured by all the tangible and invisible evils of society, and finally became a pathetic victim.
\end{abstract}

Key Words: Thomas Hardy; Tess's character; external factors; internal factors.

\section{INTRODUCTION}

Tess of the D 'Urbervilles is both a tragedy of love and a tragedy of life. Tragedy is the process of a variety of conflict of various contradictions by the characters and the social environment, the cause of the tragedy is dominated by the characters and environment. It was the result of Tess's social, economic, political and class status that caused her tragedy life. Tess lived in an era of alternation between the old and the new, and was born into a peasant family, bound by some old moral and fatalistic views. The novel is part of a novel called "character and environment" by Hardy. Tess of the D 'Urbervilles was portrayed as a modern woman suffering from old moral persecution and a new agricultural worker. The character of Tess was typical of the revelation and prosecution of the whole system at that time.

\section{TESS IN THOMAS HARDY'S EYES}

Thomas hardy (1840-1928) is the outstanding realistic writer. His works include a full-length novel Tess of the D 'Urbervilles, Jude the Obscure, and the Novella, which are collected in the collection of a changed man. Tess is one of the most successful images of Hardy. The writer molded Tess into a fine man, and depicted the pure girl in a sincere tone. In the eyes of the world, she was a sinner, a fallen woman, a dependent mistress, and finally a murderer. But to Hardy, Tess was born beautiful, kind and simple, and dare to self-sacrifice, with rich and noble feminine temperament; She is strong-willed and passionate, as well as a symbol of beauty and a personification of love. She embodies both the tradition and the characteristics of The Times, with a high degree of generality, typicality and symbolism. Tess is a representative of the hire peasant class suffered insult, pain, exploitation and destruction from the impact of capitalism, represents the peasant class in the rural area of south of England.

Hardy's views were sharply divided against the prejudices of society and the moral standards of that time. Hardy's insistence on moral purity lies in the purity of the mind, not in a moment's fault, so that Tess is "a pure woman". The society insists on the traditional custom that the fault of the moment is the unredeemable depravity, and Tess is a sinner who commits adultery. Hardy believes there is no perfect man in the world, the person's "perfect" is embodied in the understanding of life, love of life, rich feelings and devoted love, can only be produced from such a perfect purity. Hardy severely criticized Angel Clare which represents the bourgeois ethics, pointed out that it has become people's spiritual shackles. 
TESS'S CHARACTER REFLECTED IN THE NOVEL

\section{Love life, Diligence,Kindness, Simple, Strong and Brave}

Tess is the daughter of peasants, but she loved the current names, unwilling to clenching aristocracy, she thought her everything, even the beauty is "peasant's mother to her," she loved life, dared to bear the burden of the family. For the sake of their families, she had to work on D'Urbervilles' farm, then she went to the dairy farm, and as life became more difficult, she had to go to work everywhere, which showed her diligence and kindness.

Tess was abandoned by D 'Urbervilles, and was ridiculed and reviled by the people around her; when the baby was born, Tess called the younger brothers to perform christening for her children, she suffered in silence and lived bravely.

\section{Loyalty and Honesty to Love}

Tess, worried that her identity had a negative effect on Clare, tried to restrain herself and try to avoid him. She thought of Claire everywhere, and even asked other girls to contact Claire to help him choose his ideal mate. When the repressed love broke through, Tess instantly became single-minded, and she pinned all her hopes on Clare. On the wedding night, to show of her loyalty and love to Clare,Tess confessed to Claire that she had lost her virginity in D 'Urberville. She has done with repeated declarations and detailed explanations, without any vindication charges, no tears, no complaints. After hearing this, Clare made an unseemly gesture: he fiddled with the fire in the stove, and in the face of Clare's silence. Tess's love was real and complete.

\section{Tess's Resistance and Belligerence}

Although Tess was no longer a virgin, she had always held a kind of inviolable attitude towards Alec. She gave up the comfort life she could have enjoyed and raised the children alone. The discrimination around her did not frighten her, she endured the injustice of life. In order to bring the child to rest after death, she took the risk of blasphemy and baptized the child herself. Although life gave her only a blow and a disaster, she was able to bear it with no more demands. Tess's second encounter with Alec was the most difficult time of her life. She was unmoved by Alec's temptations, even "clenching the back of the glove, and being angry at his face... Where the glove was struck, a red print of blood was seen, and a moment later the blood ran down, dripping from the mouth to the bundle", it was such a strong resistance that Tess would not compromise.

Tess had once again committed herself to Alec, for the sake of her mother and her brothers and sisters. But her fight did not end there. The surrender was temporary. In the end, she killed him, which was the inevitable result of her inner rebellion, and sooner or later she would settle the crime of Alec. Tess's violent anti - evil ending was the sublimation of her character.

\section{EXTERNAL FACTORS THAT INFLUENCE TESS'S CHARACTER}

\section{Social Environment Factors}

Tess was born in an era of old and new, and was bound to be influenced by certain old notions of morality and fatalism. Tess was born into a peasant family, thus some of the old morals and fatalism that remained with the peasants gave her a weak side against traditional morality. She was persecuted by secular public opinion and traditional morality, she still viewed herself with this moral standard and believed that she was guilty. It is the deep-rooted feudal concept of society and the virgin complex of her lover that caused the later tragedy, "She saw herself as the embodiment of evil," she said. "she always felt that people all over the world were watching her and dared not look up." she was more than anyone else to forget her shame. Tess was bound by a moral compass she had woven herself. In fact, her self-restraint consciousness has a deep historical foundation and is the concrete manifestation of the whole social 
consciousness. As an individual in a certain historical period, Tess will inevitably form social consciousness and moral concept in a certain historical period, and her thoughts and actions are bound to be restricted by The Times and social consciousness.

\section{Family Factors}

Tess's father was a poor, lazy, alcoholic and ignorant country hawker, while her mother used to be a dairymaid, superstitious and simple, both her parents are the little people and the poor. The idea of clenching the aristocracy made Tess's parents force Tess to come to the town to recognize her family, which led to the continuation of the tragedy. It was such a pair of poor parents that became the author of Tess's tragedy. In order to show his so-called "aristocracy" status, in order to satisfy the humble vanity, Tess's parents tried to improve their status by "marriage".

Poor family poverty was the first and most immediate cause of Tess's tragic fate, and Tess would not have to go to the market overnight if it were not for family poverty. If it were not for poverty, the parents would not force her to marry; If it were not for poverty, Tess would not have suffered so much humiliation in Clare's absence, and would not have been married to Alec. Thus, poverty is indeed one of the most important conditions for Tess's tragic fate.

\section{THE INTERNAL FACTORS THAT INFLUENCE TESS'S CHARACTER}

\section{Tess's Personality Traits}

Tess's beauty and temperament were in harmony with nature, and she was the daughter of nature. She is like a grass, free to grow on the open field. She was unworldly, kind and sympathetic. Tess had never hurt a fly or a worm, and even a bird in a cage made her cry. Tess's character determined that she was incapable of protecting herself, exposed herself without any defence, and paid more than she could afford. The tragic nature of her fate had already set the tone, and it was only a matter of time before the tragedy occurred, or the manifestation might be different. Tess also had a very recessive nature, which was her longing for and love for existence. Tess was pure, beautiful, and kind, and she was compassionate, responsible and rebellious, but with low literacy. Through the analysis of the image of Tess, the author reveals that Tess's misfortune is not only a social tragedy, but also a tragedy of character, which reinforces the tragic appeal of Tess.

\section{Low Literacy}

Tess was born into a family of small aristocrats that had long been in decline, and lived in an era of old and new, the daughter of a poor peasant, who was bound to be influenced by certain old notions of morality and fatalism. Tess had a deep-rooted feudal concept and feudal thought. In her time, farmers were low in education, low in culture, low in knowledge, and simple in simplicity. Tess's education was a feudal idea, which had a great influence on Tess's later fate, and was a major contributing factor to her tragic fate.

\section{CONCLUSION}

Tess is a woman who suffers from old moral persecution, and has typical significance to expose and accuse the whole system of the hypocritical ethics and morality of the bourgeoisie.

\section{References:}

GAO Yu-fen, An Analysis of the Tragedy of Tess from Four Aspects.[J], Journal of Liaoning No rmal University (Social Science Edition), 2006.

$\mathrm{Xu}$ Yi, The character Analysis of the Heroine in the Classic British Novel Tess of the D'Urbervilles.[J], Examination Weekly, 2015. 
Wang Shou-ren, Selections of English literature (second edition).[M], Beijing: Advanced Education Publishing House, 2005.

Wang Yu-zhi, Tess of D 'Urberville.[M], Shanghai: Shanghai Foreign Language Education Publishing House, 2001.

Wu Hou-ka, Foreign Literary Classics.[M], Sichuan: Sichuan Publishing House, 2006. 